\title{
PELAKSANAAN PENYALURAN ZAKAT OLEH BAITUL MAL ACEH SEBAGAI PENDAPATAN ASLI DAERAH DALAM UNDANG-UNDANG NOMOR 11 TAHUN 2006 TENTANG PEMERINTAHAN ACEH
}

\author{
Ristyana Tri Hastuti \\ (Mahasiswa Program S1 Fakultas Hukum Universitas Tarumanagara) \\ (E-mail: ristyanatri@gmail.com)
}

\begin{abstract}
Ahmad Redi
(Corresponding Author)

(Dosen Hukum Tata Negara, Universitas Tarumanagara. Meraih Sarjana Hukum (S.H) dari Universitas Diponogoro (2007), Magister Hukum (M.H) dari Universitas Indonesia (2009) dan

Doktor Ilmu Hukum (Dr.) dari Universitas Indonesia (2013))

(E-mail: ahmadr@fh.untar.ac.id)

Aceh is a province in Indonesia granted with a special authority to govern and manage its own government affairs. Among the special authorities is to include zakat into the locally-generated revenues. The provisions of zakat as locally-generated revenues are set out in Law No. 11 of 2006 on Aceh Government. The Baitul Maal is established by the Qanun to manage the zakat funds. The currently emerging issue is Article 10 of Governor Regulation No. 2015 stating that zakat can be distributed prior to the passage of APBA (Aceh local budget). The central issues are whether zakat can be distributed without passing through the APBA mechanism and what is the ideal arrangement for the zakat. The present study used the normative research method by utilizing secondary data supported by interviews. Results showed that the zakat funds could not be distributed prior to the approval of APBA since the officials in charge of it were reluctant to act accordingly. Furthermore, zakat should ideally be regulated to be special locally-generated revenues, rather than including it into the locally-generated revenues, in order not to delay its distribution.
\end{abstract}

Keywords: Zakat, locally-generated revenues, zakat management and distribution 


\section{Pendahuluan}

\section{A. Latar Belakang}

Secara yuridis formal,pengaturan syariat Islam di Aceh didasarkan pada Pasal 18 Undang - Undang Dasar Negara Republik Indonesia Tahun 1945, Undang -Undang nomo 44 Tahun 1999 tentang Pemyelenggaraan Keistimewaan Aceh dan Undang- Undang Nomor 11 Tahun 2006 tentang Pemerintahan Aceh. kedua undang-undang ini menjadi dasar kuat bagi Provinsi Aceh untuk menjalankan syariat Islam. Hal ini menandakan syariat Islam adalah bagian dari kebijakan negara yang diberlakukan di Provinsi Aceh. Oleh karena itu, dalam konteks pelaksanaannya pun tidak terlepas dari tanggungjawab negara.

Bagi muslim, zakat merupakan perintah dari rukun Islam dan menjadi salah satu unsur yang paling penting dalam menegakkan syariat Islam. Zakat adalah harta tertentu yang wajib dikeluarkan oleh orang beragama Islam dan diberikan kepada golongan yang berhak menerimanya. Zakat digunakan untuk membantu masyarakat yang membutuhkan dan menstabilkan ekonomi masyarakat. Zakat sangat berpotensi sebagai sebuah sarana yang efektif untuk memberdayakan ekonomi masyarakat. Potensi itu apabila digali secara optimal dari seluruh masyarakat Islam dan dikelola dengan baik dengan manajemen amanah dan profesionalisme yang tinggi, akan mewujudkan sejumlah dana yang besar yang bisa dimanfaatkan untuk meningkatkan perekonomian dan kesejahteraan masyarakat. ${ }^{1}$

Negara mengatur tentang pengelolaan zakat agar tidak bertentangan dengan prinsip syariat. Pengelolaan zakat yang dijalankan negara bertujuan demi terciptanya kesatuan sistem. Makna pengelolaan zakat dirumuskan secara jelas dalam Pasal 1 angka 1 Undang-Undang Nomor 3 Tahun 1999 tentang Pengelolaan Zakat yaitu, kegiatan perencanaan, pengorganisasian, pelaksanaan dan pengawasan terhadap pengumpulan dan pendistribusian serta pendayagunaan zakat. $^{2}$

\footnotetext{
${ }^{1}$ Indonesia Zakat Development Report, Menggagas arsitektur Zakat di Indonesia( Ciputat : Indonesia Magnificence of Zakat (IMZ),2010), 111.

${ }^{2}$ Indonesia, Undang-Undang Nomor 3 Tahun 1999 tentang Pengelolaan Zakat, Pasal 1 angka 1
} 
Provinsi Aceh sebagai daerah otonom yang menerapkan pelaksanaan syariat Islam memiliki peraturan yang kuat dan komprehensif dalam mengatur pengelolaan zakat sebagai salah satu instrumen ekonomi Islam yang dapat diandalkan. Undang-Undang Nomor 44 Tahun 1999 tentang Penyelenggaraan Keistimewaan Aceh dan Undang-Undang Nomor 18 Tahun 2001 tentang Otonomi Khusus menjadi landasan awal terbentuknya lembaga Baitul Mal di Aceh sebagai lembaga resmi pengelola zakat. Kedua undang-undang tersebut menjadi dasar lahirnya Qanun Nomor 7 Tahun 2004 tentang Pengelolaan Zakat.

Dalam Pasal 4 ayat (2) Undang-Undang Nomor 18 Tahun 2001 tentang Otonomi Khusus disebutkan bahwa zakat sebagai sumber pendapatan asli daerah (PAD). Kemudian dalam Pasal 180 ayat (1) Undang-undang Nomor 11 Tahun 2006 tentang Pemerintahan Aceh menyebutkan ${ }^{3}$;

1. Sumber Pendapatan Asli Daerah (PAD) Aceh dan PAD Kabupaten/Kota sebagaimana diatur dalam Pasal 179 ayat (2) huruf a terdiri atas:

a. Pajak daerah;

b. Retribusi daerah;

c. Hasil pengelolaan kekayaan daerah yang dipisahkan milik Aceh/Kabupaten/Kota dan hasil modal Aceh/Kabupaten/Kota;

d. Zakat; dan

e. Lain-lain pendapatan daerah Aceh dan pendapatan asli Kabupaten/Kota.

Secara normatif pendapatan asli daerah (PAD) adalah pendapatan yang diperoleh daerah berdasarkan peraturan daerah sesuai dengan peraturan perundang-undangan dan hasilnya dimanfaatkan untuk penyelenggaraan tugastugas pemerintah dan kegiatan pembangunan dalam rangka mengisi kemandirian otonomi daerah.

Pengelolaan zakat sebagai pendapatan asli daerah juga disebutkan dalam Pasal 24 ayat (2) sampai 5 Qanun Aceh Nomor 10 Tahun 2007 tentang Baitul Mal, bahwa ${ }^{4}$ :

\footnotetext{
${ }^{3}$ Indonesia, Undang-undang Nomor11 Tahun 2006 tentang Pemerintahan Aceh, Pasal 180 ayat (1).

${ }^{4}$ Indonesia, Qanun Aceh Nomorl0 tahun 2007 tentang Baitul Mal, Pasal 24 ayat (2).
} 
1. Semua penerimaan zakat yang dikelola Baitul Mal Aceh merupakan sumber PAD Aceh yang harus disetor ke Kas Umum Daerah Aceh.

2. PAD Aceh sebagaimana dimaksud pada ayat (2) disimpan dalam rekening tersendiri Bendaharawan Umum Daerah (BUD) Aceh yang ditunjuk Gubernur.

3. Pengumpul dana hasil zakat disampaikan pada rekening tersendiri sebagaimana dimaksud pada ayat (3) hanya dapat dicairkan untuk kepentingan program dan kegiatan yang diajukan oleh kepala Baitul Mal Aceh sesuai dengan asnaf masing-masing.

4. Ketentuan lebih lanjut mengenai tata cara pembayaran zakat oleh muzakki dan pencairan dana zakat oleh Baitul Mal Aceh dari Bendaharawan Umum Daerah (BUD) diatur dengan peraturan Gubernur.

Dalam Qanun Aceh Nomor 10 Tahun 2007 tentang Baitul Mal tidak menjelaskan secara konkrit lembaga mana yang berwenang dalam melakukan pengawasan pengelolaan dana zakat apalagi dana zakat yang dihimpun menjadi salah satu sumber PAD, dan bagaimana mekanisme penyaluran zakat tersebut. Dengan Demikian, bila dilihat menurut sistem keuangan daerah maka zakat harus diperlakukan sama seperti sumber-sumber PAD lainnya. Zakat juga harus dilakukan pengawasan oleh pemerintah karena dana yang dikumpulkan merupakan tanggung jawab Kepala Daerah dan juga merupakan perintah agama.

Pada dasarnya, zakat yang dimasukkan ke pendapatan asli daerah yang dalam pengelolaan menganut ketentuan keuangan daerah merupakan suatu hal yang baru di Indonesia, khususnya Provinsi Aceh, akan tetapi saat implementasinya pada saat penyaluran zakat tersebut yang bersumber dari PAD masih terdapat permasalahan seperti pengelolaan dana zakat tersebut.

PAD merupakan pendapatan daerah yang digunakan untuk memenuhi kebutuhan daerah pada tahun anggaran. Penghitungan PAD dilakukan satu kali setahun pada rapat pengesahan Anggaran Pendapatan dan Belanja Aceh (APBA), sedangkan zakat merupakan harta yang wajib dikeluarkan oleh muslim atau badan usaha untuk diberikan kepada yang berhak menerimanya sesuai dengan syariat Islam. Konsep zakat sebagai satu sumber PAD dibenarkan dengan peraturan di atas, hanya saja kendala utamanya adalah realisasi penyaluran zakat 
itu terkendala pengesahan APBA yang merupakan agenda rapat tahunan, sedangkan realisasi zakat tidak dapat menunggu konsesi tahunan tersebut. Melihat zakat dalam balutan birokrasi akan semakin sulit untuk direalisasikan, sehingga menyebabkan zakat menjadi sekarat, karena para asnaf harus menunggu waktu yang lama.

Dalam Pasal 10 Peraturan Gubernur Aceh Nomor 6 Tahun 2015 tentang Tata Cara Penerimaan dan Pencairan Dana Zakat Pada Kas Umum Aceh menyatakan bahwa untuk menjaga kesinambungan penyaluran zakat kepada mustahik, Baitul Mal dapat mencairkan dana zakat yang sudah disetor ke Kas Umum Aceh tanpa menunggu pengesahan Qanun APBA, setinggi-tingginya sebesar sisa realisasi penerimaan zakat tahun anggaran sebelumnya. ${ }^{5}$ Namun dalam pelaksanaannya sampai saat ini bahwa penyaluran atau pencairan dana zakat tersebut belum dapat dilaksanakan sampai dengan APBA itu disahkan oleh Dewan Perwakilan Rakyat Aceh (DPRA).

Baitul Mal mengalami kesulitan dalam pengelolaan zakat,terutama dalam proses pengumpulan dan pengeluaran dari Dinas Keuangan Aceh. Jika jumlah zakat yang diterima lebih besar dari zakat yang direncanakan dalam Dokumen Pelaksanaan Anggaran oleh Sekretariat Baitul Mal, maka dana zakat yang lebih dari perencanaan tidak dapat ditarik atau dikeluarkan kembali. Hal ini disebabkan proses pengeluarannya harus mengikuti mekanisme perencanaan yang ada, dana zakat tersebut akan menjadi Sisa Lebih Pembiayaan Anggaran Tahun Berkenaan (SILPA).

Dalam mekanisme APBA, pengesahan anggaran menjadi sebuah pegangan dan tidak bisa diubah kecuali melalui mekanisme tersendiri yaitu melalui revisi anggaran, sedangkan zakat yang diterima (yang telah dimasukan dalam PAD) ketentuannya tetap harus disalurkan seluruhnya, baik jumlahnya sedikit maupun banyak, telah direncanakan tahun sebelumnya atau direncanakan ditahun berjalan.

Sasaran pengelolaan dana PAD dan zakat sebenarnya sudah berbeda, dan jika digabungkan malah menimbulkan beban baru birokrasi, yang sama sekali

\footnotetext{
${ }^{5}$ Indonesia, Peraturan Gubernur Nomor 6 tahun 2015 tentang Tata Cara Penerimaan dan Pencairan Dana Zakat pada Kas Umum Aceh, Pasal 10.
} 
tidak ada efeknya terhadap pemasukan daerah, karena objek penerima zakat sudah pasti bukan birokrasi. Konsep zakat di Aceh masih menitik-beratkan pada biaya wajib untuk diberikan pada yang berhak menerima, bukan biaya birokrasi. Kemudian objek realisasi zakat harus jelas, apakah untuk para mustahiq atau kegunaan dana zakat dapat diperluas maknanya sebagai bagian dari pendapatan daerah yang dapat digunakan untuk keperluan daerah. Dengan konsep zakat bagian dari PAD, seharusnya dana zakat dalam tahun berjalan dibagikan kepada mustahiq secara langsung, dan bukan dikumpulkan terlebih dulu baru dibagikan pada tahun berikutnya.

Apabila dana zakat mengendap selama setahun sebagai SILPA, ini bisa saja digunakan untuk keperluan lainnya pada tahun berjalan sebelum dana zakat tersebut dibagikan pada tahun berikutnya. Untuk itu, diperlukan suatu mekanisme yang mengatur tentang dana zakat sebagai PAD serta mengelolaannya.

Oleh karena itu, peneliti tertarik untuk melakukan penelitian ke dalam tulisan jurnal mahasiswa yang berjudul "Pelaksanaan Penyaluran Zakat Oleh Baitul Mal Aceh Sebagai Pendapatan Asli Daerah Dalam Undang-Undang Nomor 11 Tahun 2006 Tentang Pemerintahan Aceh”

\section{B. Perumusan Masalah}

Berdasarkan latar belakang yang telah dikemukakan, maka yang menjadi rumusan permasalahan adalah sebagai berikut:

1. Apakah penyaluran dana zakat dapat direalisasikan tanpa melalui mekanisme APBA ?

2. Bagaimanakah pengaturan ideal agar dana zakat sebagai PAD dapat disalurkan tanpa melalui mekanisme keuangan daerah ?

\section{Pembahasan}

\section{A. Realisasi penyaluran zakat tanpa melalui mekanisme APBA}

Zakat adalah suatu kewajiban bagi umat Islam yang telah ditetapkan dalam Alquran, sunah nabi dan ijma' para ulama. Zakat merupakan salah satu rukun 
Islam yang selalu disebutkan sejajar dengan shalat. Inilah yang menunjukan betapa pentingnya zakat sebagai salah satu rukun Islam. ${ }^{6}$

Zakat dari segi istilah fikih berarti sejumlah harta tertentu yang diwajibkan Allah diserahkan kepada orang - orang yang berhak disamping berarti mengeluarkan jumlah tertentu itu sendiri. Jumlah yang dikeluarkan dari kekayaan itu disebut zakat karena yang dikeluarkan itu. ${ }^{7}$ Tujuan dari adanya zakat yaitu untuk mengangkat derajat fakir miskin dan membantunya keluar dari kesulitan hidup serta penderitaan, membentangkan dan membina tali persaudaraan antar umat Islam pada umumnya serta menjembtani jurang pemisah antara yang kaya dan yang miskinn dalam suatu masyarakat.

Undang-Undang Nomor 11 Tahun 2006 tentang Pemerintahan Aceh ini adalah undang-undang yang dibentuk untuk menggantikan Undang-Undang Nomor 18 Tahun 2001 tentang Otonomi Khusus Bagi Provinsi Daerah Istimewa Aceh Sebagai Provinsi Nanggroe Aceh Darussalam. Undang-Undang Pemerintahan Aceh ini tidak terlepas dari Nota Kesepahaman (Memorandum of Understanding) selanjutnya disebut MoU Helsinky antara Pemerintah Indonesia dan Gerakan Aceh Merdeka yang ditandatangani pada tanggal 15 Agustus 2005 dan merupakan suatu bentuk rekonsiliasi secara bermartabat menuju pembangunan sosial, ekonomi, serta politik di Aceh secara berkelanjutan. ${ }^{8}$

Isi dari MoU Helsinky tersebut menginginkan Pemerintahan Aceh menjalani roda pemerintahannya sendiri, dan diberi keistimewaan dalam melakukan kebijakan-kebijakan lokal tanpa campur tangan dari pemerintah pusat. Pemerintah Aceh akan melaksanakan kewenangan dalam semua sektor publik, yang akan diselenggarakan dengan administrasi sipil dan peradilan, kecuali dalam bidang hubungan luar negeri, pertahanan luar negeri, keamanan nasional, moneter,

\footnotetext{
${ }^{6}$ Abdul Al- Hamid, Ekonomi Zakat: Sebuah kajian moneter dan keuangan syariah (Jakarta : PT raja Grafindo Persada, 2006 ),1.

${ }^{7}$ M. Yusuf Qardawi, Hukum zakat, Studi Komparatif mengenai status dan filsafat zakat berdasarkan Qur'an dan Hadits, Diterjemahkan oleh Salman Harun, et.al, (Jakarta : Litera antarNusa,1987),34.

${ }^{8}$ Indonesia, Naskah Akademik Rancangan Undang-Undang Nomor 11 Tahun 2006 Tentang Pemerintahan Aceh, 15.
} 
dan fiskal, kekuasaan kehakman dan kebebasan beragama, kebijakan tersebut merupakan kewenangan Pemerintah republik Indonesia sesuai dengan konstitusi.

Dasar kesepakatan dari MoU Helsinky ini yang mengakibatkan terbentuknya undang - undang Pemerintahan Aceh adalah karena terdapat berbagai kebijakan dalam pengaturan pemerintahan daerah Provinsi Aceh pada masa lalu telah menyebabkan terjadinya ketidakadilan diberbagai perikehidupan rakyat Aceh, keresahan, pergolakan, dan bahkan menimbulkan perlawanan secara fisik bersenjata melalui Gerakan Aceh Merdeka terhadap pemerintah pusat. Dalam Mou Helsinky ini telah disetujui beberapa hal, yaitu pertama, Pemerintah Republik Indonesia dan Gerakan Aceh Merdeka menegaskan komitmen untuk menyelesaikan Konflik Aceh secara damai, menyeluruh, berkelanjutan dan bermartabat bagi semua. kedua, Pemerintah Republik Indonesia dan Gerakan Aceh Merdeka bertekad untuk menciptakan kondisi sehingga pemerintahan di Aceh dapat diwujudkan melalui suatu proses yang demokratis dan adil dalam Negara Kesatuan Republik Indonesia. Ketiga, kedua belah pihak yang terlibat dalam konflik sangat yakin bahwa hanya dengan penyelesaian damai atas konflik tersebut yang akan memungkinkan pembangun kembali Aceh pasca Tsunami tanggal 26 Desember 2004 dapat mencapai kemajuan dan keberhasilan. Keempat, kedua belah pihak yang terlibat dalam konflik bertekad untuk membangun rasa saling percaya. ${ }^{9}$

Baitul Mal adalah lembaga agama Islam di Provinsi Aceh yang berwenang mengurus dan mengelola harta agama dengan tujuan untuk kemaslahatan umat serta menjadi wali pengawas berdasarkan syariat Islam. Qanun Aceh Nomor 10 Tahun 2007 tentang Baitul Mal menyebutkan bahwa Baitul Mal Aceh adalah lembaga daerah non struktural yang memiliki kewenangan untuk mengelola dan mengembangkan zakat, wakaf, harta agama lainnya dengan tujuan untuk kemaslahatan umat, serta menjadi wali/wali pengawas terhadap anak yatim piatu dan/atau pengelola harta warisan yang tidak memiliki wali berdasarkan syariat 
Islam. Baitul Mal terdiri dari empat tingkatan, yaitu tingkat Provinsi, Kabupaten/Kota, Kemukiman, dan Gampong. ${ }^{10}$

Baitul Mal adalah institusi khusus untuk menangani harta yang diterima oleh negara dan mengalokasikannya bagi kaum muslim yang berhak menerimanya. Setiap harta, baik berupa tanah, uang, barang tambang, bangunan maupun harta benda lainnya sebagai kaum muslim berhak memilikinya sesuai hukum syariat yang tidak ditentukan individu pemiliknya walaupun ditentukan jenis hartanya, maka harta tersebut adalah hak Baitul Mal kaum muslim. Tidak ada perbedaan, baik yang sudah masuk ke dalamnya maupun yang belum. Demikian pula setiap harta yang wajib dikeluarkan untuk orang-orang yang berhak menerimanya, untuk kemaslahatan kaum muslim dan pemeliharaan urusan mereka, serta untuk biaya mengemban dakwah, merupakan kewajiban atas Baitul Mal, baik dikeluarkan secara riil maupun tidak. Baitul Mal dengan pengertian seperti ini adalah sebuah lembaga. ${ }^{11}$

Pembentukan awal lembaga formal pengelola zakat di Aceh dimulai tahun 1973 melalui Keputusan Gubernur Kepala Daerah Istimewa Aceh No. 5/1973 Tentang Pembentukan Badan Penertiban Harta Agama (BPHA). BPHA ini kemudian dirubah dalam tahun 1975 menjadi Badan Harta Agama (BHA). Sehubungan dengan adanya Keputusan Bersama Menteri Agama dan Menteri Dalam Negeri tahun 1991 Tentang Pembentukan BAZIS (Badan Amil Zakat, Infak dan Shadaqah). Perubahan BHA menjadi BAZIS di Aceh dilakukan dalam tahun 1998, dengan struktur yang agak sedikit berbeda dengan BAZIS didaerah lain secara nasional, yaitu mulai BAZIS Provinsi, Kabupaten/Kota dan Kecamatan. Sedangkan BAZIS Aceh terdiri dari Provinsi, Kabupaten/Kota, Kecamatan dan Gampong/Kelurahan. Perubahan BAZIS menjadi Badan Baitul Mal Provinsi Aceh dilakukan melalui Keputusan Gubernur No. 18/2003 tentang Pembentukan Organisasi dan Tata Kerja Badan Baitul Mal Provinsi Nanggroe Aceh Darussalam, yang mulai beroperasi pada bulan Januari 2004. ${ }^{12}$

\footnotetext{
${ }^{10}$ Anonim, "Sejarah Baitul Mal Aceh", http://baitulmal.acehprov.go.id, 5 Mei 2018

${ }^{11}$ Abdul Qaddim Zallum, Sistem Keuangan Negara Khalifah (Jakarta selatan: HTI Press,2009), 17 .

${ }^{12}$ Naskah akademik, Op.cit., 15
} 
Pembentukan Badan Baitul Mal di Aceh tahun 2003 adalah sebagai bagian dari pelaksanaan syariat Islam secara kaffah. Ada kerinduan muslimin Aceh mengaktualkan kembali institusi yang pernah eksis dalam sejarah Islam. Bahkan, kewenangan Baitul Mal ketika itu tak sebatas mengelola harta agama, tapi berfungsi sebagai Kas Negara (Islam). Terakhir, melalui SK Gubernur Aceh Nomor 18 tahun 2003, sebagai implementasi UU Nomor 44 Tahun 1999 tentang Penyelenggaraan Keistimewaan Aceh dan selanjutnya diperkuat dengan Qanun Aceh Nomor 10 tahun 2007 Tentang Baitul Mal, yang merupakan amanah pasal 191 Undang-Undang Nomor 11 tahun 2006 Tentang Pemerintahan Aceh, maka dibentuklah lembaga pengelola zakat di Provinsi Aceh dengan nama Baitul Mal Aceh hingga saat ini.

Adapun fungsi dan kewenangan Baitul Mal tercantum dalam Qanun Nomor 10 Tahun 2007 pasal 8 ayat 1 yaitu $^{13}$ :

a. Mengurus dan mengelola zakat, wakaf dan harta agama

b. Melakukan pengumpulan, penyaluran dan pendayagunaan zakat;

c. Melakukan sosialisasi zakat, wakaf, dan harta agama lainnya;

d. Menjadi wali terhadap anak yang tidak mempunyai lagi wali nasab, wali pengawas terhadap wali nashab, dan wali pengampu terhadap orang dewasa yang tidak cakap melakukan perbuatan hukum;

e. Menjadi pengelola terhadap harta yang tidak diketahui pemilik atau ahli warisnya berdasarkan putusan Mahkamah Syariah; dan

f. Membuat perjanjian kerjasama dengan pihak ketiga untuk meningkatkan pemberdayaan ekonomi umat berdasarkan prinsip saling menguntungkan.

Tugas pokok dan fungsi Baitul Mal Aceh diperluas menjadi wali pengawas dan menjadi pengelola terhadap tanah, harta dan simpanan nasabah bank yang tidak ada pemilik/ahli warisnya lagi akibat tsunami. Ketentuan ini diatur dengan Undang-Undang Nomor 48 Tahun 2007 tentang Penetapan Perpu Nomor 2 Tahun 2007 tentang Penyelesaian Permasalahan Hukum Dalam Rehab Rekon di Aceh. Undang-undang ini telah memberi kewenangan kepada Baitul Mal Aceh untuk

${ }^{13} \mathrm{Ibid}$. 
menjadi wali/wali pengawas dan pengelola harta tanpa ahli waris, setelah mendapat penetapan Mahkamah Syariah. Selanjutnya untuk memperkuat keberadaan Baitul Mal sebagai lembaga daerah yang bersifat non struktural dan independent, dengan Permendagri Nomor 18 Tahun 2008 tentang Organisasi dan Tata Kerja Lembaga Keistimewaan Aceh telah diatur pemberian eselonisasi sekretariat Baitul Mal Aceh. Sekretariat tersebut merupakan perangkat daerah sebagai unsur pemberi pelayanan administratif. ${ }^{14}$

Struktur organisasi dari Lembaga Non Struktural Baitul Mal Provinsi Aceh terbagi atas 2 bagian, yaitu Badan Pelaksana dan Sekretariat Baitul Mal Aceh. Badan Pelaksana Baitul Mal Aceh terdiri atas beberapa bagian, yaitu bidang pendistribusian dan pendayagunaan, bidang pengawasan, bidang pengumpulan, bidang perwalian dan bidang sosialisasi dan pengembangan, sedangkan Sekretariat Baitul Mal Aceh terdiri atas 3 bagian, yaitu bagian umum, bagian keuangan dan bagian hukum dan hubungan umat. ${ }^{15}$ Untuk menjalankan fungsi dan kewenangan tersebut Baitul Mal Aceh didukung tiga unsur utama organisasi, yaitu Badan Pelaksana, Dewan Pertimbangan Syariah, dan Sekretariat. Badan pelaksana adalah unsur pengelola zakat, infaq, sedekah, wakaf,dan harta agama lainnya yang dipimpin oleh seorang kepala yang berada di bawah dan bertanggung jawab langsung kepada Gubernur Aceh. Dewan Pertimbangan Syariah adalah unsur kelengkapan Baitul Mal Aceh yang memiliki kewenangan untuk memberikan pertimbangan syariah, pengawasan fungsional, dan menetapkan pengelolaan zakat, wakaf, dan harta agama lainnya kepada Baitul Mal Aceh, termasuk Baitul Mal Kabupaten/Kota. Sekretariat adalah unsur penyelenggara pelaksanaan tugas dan fungsi Baitul Mal Aceh, serta menyediakan dan mengkoordinasikan tenaga ahli yang diperlukan Baitul Mal Aceh. ${ }^{16}$

Dalam pasal 180 ayat (1) Undang-Undang Pemerintahan Aceh telah dijelaskan bahwa zakat di Aceh menjadi bagian pendapatan asli daerah yang

\footnotetext{
${ }^{14}$ Hayatullah Zuboidi et al, Laporan Tahunan Annual Report 2017 (Banda Aceh: Baitul Mal Aceh , 2017), 6.

${ }^{15}$ Shafwan Bendadeh et al, Laporan Tahunan Annual Report 2014 (Banda Aceh: Baitul Mal Aceh , 2014), 6 .

${ }^{16}$ Ibid.
} 
secara otomatis akan langsung dikelola oleh Pemerintah Aceh dan harus mengikuti mekanisme pendapatan asli daerah lainnya. Berdasarkan UndangUndang Pemerintahan Aceh tersebut maka lahirlah sebuah qanun atau peraturan daerah yang mengatur mengenai sebuah badan atau lembaga independen yang bertanggungjawab langsung kepada Gubernur Aceh berdasarkan Qanun Aceh Nomor 10 Tahun 2007 tentang Baitul Mal yang bertugas untung menghimpun dan menyalurkan zakat secara langsung dalam berbagai bentuk kepada asnaf.

Zakat sebagai PAD merupakan kekhususan Aceh sebagai satu-satunya daerah di Indonesia yang menerapkannya. Zakat sebagai PAD dalam pengelolaannya menganut ketentuan keuangan daerah tanpa mempertimbangkan zakat sebagai bagian dari perintah agama. Padahal, zakat dalam agama begitu terkumpul harus segera disalurkan dan tidak perlu menunggu pengesahan APBA (seperti PAD murni), karena yang dicairkan adalah uang zakat yang disetor ke kas daerah. Zakat yang disetor ke kas daerah menjadi PAD murni dianggap telah melanggar prinsip-prinsip syariah.

Ketentuan zakat sebagai pendapatan asli daerah ini dibentuk dengan salah satu alasan mendasar, yaitu karena para pakar di Aceh dan tokoh -tokoh masyarakat ingin zakat di Aceh ini dielola dengan baik. Ide-ide ini muncul dari kekhawatiran masyarakat ketika melihat perkembangan lembaga zakat yang sangat lambam terutama jika dilihat dari segi manajemen pengelolaannya. Kondisi ini tidak boleh dibiarkan apalagi zakat merupakan potensi terbesar dalam memberantas kemiskinan setelah Aceh dilanda gempa dan tsunami pada Desember 2004. Kemudian dari sinilah muncul gagasan antara lain bahwa kontribusi pemerintah harus lebih banyak dan besar sehingga intervensi pemerintah sangat kuat dalam pengelolaan zakat ini.

Pendapatan Asli Daerah (PAD) merupakan sumber penerimaan daerah yang asli digali di daerah yang digunakan untuk modal dasar pemerintah daerah dalam membiayai pembangunan dan usaha-usaha daerah untuk memperkecil ketergantungan dana dari pemerintah pusat. Pendapatan asli daerah (PAD) merupakan semua penerimaan yang diperoleh daerah dari sumber-sumber dalam 
wilayahnya sendiri yang dipungut berdasarkan peraturan daerah sesuai dengan peraturan perundang-undangan yang berlaku. ${ }^{17}$

Ketentuan zakat sebagai pendapatan asli daerah di Aceh seperti kebijakan fiskal atau yang sering disebut dengan politik fiskal yang pernah diterapkan oleh Rasulullah SAW. Kebijakan fiskal ini adalah langkah-langkah pemerintah untuk membuat perubahan. Perubahan dalam sistem pajak atau perbelanjaannya dengan maksud untuk mengatasi masalah masalah ekonomi yang sedang dihadapi.

Dalam pengelolaan zakat di Aceh, zakat ini sebelum disalurkan terlebih dahulu harus melalui suatu proses atau mekanisme keuangan daerah seperti pendapatan asli daerah pada umumnya, yaitu harus melalui APBA, melewati berbagai macam tahap mulai dari tahap pengumpulan, dimasukkan dalam rancangan APBA samapai disahkannya APBA itu hingga melewati sidang putusan Dewan Pertimbangan Syariah untuk dirinci secara detail penyaluran zakat tersebut. Setelah melewati proses tersebut maka dana zakat ini baru dapat direalisasikan dan disalurkan kepada para asnaf.

Zakat di Aceh ini senyatanya dapat disalurkan terlebih dahulu tanpa harus menunggu proses pengesahan APBA yang dibahas oleh DPRA bersama Gubernur karena walaupun zakat ini dimasukkan dalam pendapatan asli daerah yang dengan otomatis akan mengikuti proses atau mekanisme keuangan daerah itu namun pada kenyataannya zakat ini disimpan dalam rekening kas daerah yang berbeda dari sumber-sumber pendapatan asli daerah lainnya, sehingga dapat dikatakan senyatanya zakat ini dapat disalurkan terlebih dahulu tanpa menunggu APBA ini disahkan dengan didukungnya secara hukum untuk dapat merealisasikan penyaluran zakat tanpa menunggu APBA disahkan oleh Peraturan Gubernur tersebut sehingga ini seharusnya menjadi dasar yang kuat untuk zakat dapat segera disalurkan tanpa menunggu APBA disahkan.

Faktor terbesar dari tidak berjalan secara efektifnya Pasal 10 undang-undang itu berdasarkan wawancara dengan salah seorang Kepala Bagian di Baitul Mal Aceh adalah tidak berani dan tidak tegasnya para pejabat yang khusus menangani

\footnotetext{
${ }^{17}$ anonim, Pengertian Pendapatan Asli Daerah dan Definisi Klasifikasinya, www.landasanteori.com, 2015.
} 
masalah penghimpunan dan penyaluran dana zakat dalam hal ini adalah Kepala Baitul Mal Aceh dan Kepala Seketariat Baitul mal Aceh yang bekerja bersama dalam mengurusi penyaluran zakat untuk mengusulkan kepada Gubernur dan legislatif untuk segera dapat mencairkan dana zakat ini.

Salah satu cara untuk dapat meningkatkan penghimpunan zakat sebagai pendapatan asli daerah, yaitu diperlukannya penyamaan persepsi antara pemerintah daerah dan legislatif terhadap regulasi zakat di Aceh. Kenyataan selama ini, baru sebagian saja yaitu antara pemerintah daerah Kota/Kab dan DPRK yang menganggap penting penghimpunan zakat sebagai pendapatan asli daerah. Zakat baru dipahami sebagai bagian syariat Islam, belum menjadi otoritas negara. Di tingkat provinsi pun, persepsi ini belum sama, sehingga sinergisitas antara Baitul Mal Aceh, Sekretariat Daerah dan Dinas Pengelolaan Keuangan dan Kekayaan Aceh belum terwujud.

Pada dasarnya Peraturan Gubernur itu dibentuk agar dana zakat dapat segera disalurkan tanpa menunggu APBA disahkan karena dana zakat itu setelah dihimpun lebih baik dapat langsung disalurkan tanpa menunggu proses atau mekanisme keuangan daerah yang panjang agar sesuai dengan pengelolaan zakat secara syariat Islam, karena tidak baik dana umat dalam bentuk zakat itu diendapkan atau disimpan terlalu lama dalam kas keuangan daerah, oleh karena itu dibutuhkannya sebuah regulasi atau peraturan khusus lainnya yang dapat menopang pasal 10 Peraturan Gubernur Aceh Nomor 6 tahun 2015 ini agar pasal ini dapat diimplementasikan dengan baik dan berlaku efektif, sehingga para pejabat yang mengurusi hal ini pun menjadi lebih berani mengambil langkah untuk dapat segera mencairkan dana zakat ini tanpa harus menunggu proses pengesahan APBA yang dilakukan oleh DPRA bersama dengan Gubernur.

Konsep pendistribusian dan pendayagunaan zakat yang dikelola Baitul Mal Aceh, bukan sekadar untuk memenuhi kebutuhan para mustahiq yang bersifat konsumtif dalam waktu sesaat, akan tetapi untuk memberikan kecukupan dan kesejahteraan bagi mereka dengan menghilangkan ataupun memperkecil penyebab kehidupan mereka menjadi miskin dan menderita. Filosofi utama penyaluran zakat adalah untuk mentransformasi mustahiq menjadi muzakki. 
Karena itu, program penyaluran yang ada harus didesain dalam kerangka pemberdayaan zakat, sehingga potensi yang dimiliki mustahiq dapat dioptimalkan, dan kapasitas serta daya tahan ekonomi mereka dapat meningkat pada jangka panjang. ${ }^{18}$

Dana zakat dalam hal ini dapat didayagunakan atau dimanfaatkan dalam berbagai macam program yang setiap senif atau asnaf itu memiliki berbagai macam program, misalnya dalam senif fakir maka salah satu programnya adalah adalah santunan fakir uzur. Fakir uzur itu sendiri adalah salah satu kelompok rentan dalam masyarakat yang kondisi sosial ekonominya sangat memprihatinkan karena disamping tidak mempunyai harta dan penghasilan juga usianya yang relatif tua (manula) serta dalam keadaan sakit-sakitan (uzur). Santunan ini diberikan setiap bulannya seumur hidup mustahiq. Program ini bertujuan untuk menjamin terpenuhinya hak-hak kaum uzur yang cenderung terabaikan, sehingga mereka dapat bahagia menjalani masa-masa tuanya. kemudian ada program pemberdayaan ekonomi muallaf untuk senif muallaf. Program ini bertujuan untuk membantu muallaf secara ekonomi sebagai upaya untuk menopang kebutuhan sehari-hari. Muallaf yang mendapat bantuan modal usaha ini akan dibimbing langsung oleh fasilitator pendamping mulai dari awal usaha, proses marketing, dan pemasaran. Proses ini untuk menjamin usaha muallaf mampu menopang ekonomi keluarga dimasa akan datang.serta program - program lainnya yang setiap senif atau asnaf itu berbeda program pendayagunaannya.

Program pendayagunaan zakat ini terbagi atas 4 bagian, yaitu ${ }^{19}$ :

a. Pendidikan

Dalam sektor pendidikan ini ada beberapa program yang dijalankan oleh Baitul Mal Aceh,yaitu beasiswa penuh tingkat mahasiswa dari keluarga miskin, biaya pendidikan santri se-Aceh,beasiswa satu keluarga satu sarjana, beasiswa pendidikan berkelanjutan siswa berprestasi dari keluarga miskin tingkat SD,SMP dan SMA, dan program program lainnya

b. Sosial

\footnotetext{
${ }^{18}$ Hayatullah, Op.Cit, 15.

${ }^{19}$ Shafwan Bendadeh et al Laporan Tahunan Annual Report 2015, (Banda Aceh: Baitul Mal Aceh, 2015), 11.
} 
c. Ekonomi

Dalam sektor sosial program -program yang dilakukan antara lain santunan bulanan fakir uzur, bantuan renovasi rumah, bantuan anak terlantar dan korban kekerasan dari keluarga miskin, dan program lainnya.

Sektor ekonomi Baitul Mal Aceh memiliki beberapa program antara lain, penyaluran bantuan modal usaha untuk masyarakat miskin melalui Baitul Mal Gampong dan bantuan modal untuk muallaf.

d. Dakwah dan Syiar

Untuk sektor dakwah dan syiar Baitul mal aceh juga memiliki berbagai macam program, antara lain program kegiatan organisasi Islam dan program pendampingan syariah bagi muallaf.

Dalam hal pengawasan dana zakat ada lembaga yang secara tidak langsung ditugaskan sebagai pengawas dana zakat, karena dalam hal pengawasan dalam peraturan perundang undangan tidak diatur secara jelas siapa yang dapat mengawasi dana zakat ini. Dalam mengawasi dana zakat secara internal Baitul Mal Aceh diawasi oleh Inspektorat dalam rangka melakukan pembinaan , pengawasan terhadap dana zakat dan unsur lainnya dalam Baitul Mal Aceh. Selain Inspektorat, Dewan pertimbangan Syariah pun memiliki wewenang untuk mengawasinya proses pengelolaan zakat ini dari proses penghimpunan sampai dengan proses penyaluran.

Didalam Badan Baitul Mal Aceh ini tersendiri terdapat bidang pengawasan berdasarkan Pasal 7 Peraturan Gubernur Aceh Nomor 92 Tahun 2008 tentang Pengelolaan Keuangan Aceh menyebutkan bahwa Bidang Pengawasan mempunyai tugas melakukan monitoring, evaluasi, pengendalian dan verifikasi terhadap pendataan muzzaki, mustahiq dan pengelolaan zakat, wakaf dan harta agama. Kegiatan pengendalian dan verifikasi ini dilaksanakan oleh bidang pengawasan dengan melibatkan amil Baitul Mal Aceh lainnya, berdasarkan Surat Keputusan Kepala Baitul Mal Aceh, Surat Tugas Kepala Baitul Mal Aceh dan Surat Tugas Kepala Sekretariat Baitul Mal Aceh untuk masing-masing program. Hasil pelaksanaan kegiatan verifikasi terhadap calon mustahiq penerima bantuan dana zakat dari Baitul Mal Aceh ditetapkan dalam Keputusan Kepala Baitul Mal 
Aceh tentang penetapan nama-nama mustahiq penerima bantuan untuk masingmasing program. ${ }^{20}$

\section{B. Pengaturan ideal agar dana zakat sebagai PAD dapat disalurkan tanpa melalui mekanisme keuangan daerah.}

Ketentuan zakat sebagai pendapatan asli daerah yang diatur didalam pasal 180 Undang-Undang Nomor 11 Tahun 2006 tentang Pemerintahan Aceh dan pasal 12 dan 13 Qanun Aceh Nomor 10 Tahun 2007 tentang Baitul Mal adalah salah satu asas lex spesialis yang diberikan untuk aceh yang tidak akan didapati didaerah lainnya di Indonesia. Ketentuan ini sempat menuai berbagai macam protes dari berbagai kalangan dengan alasan karena dinilai dapat mencederai bahkan dapat bertentangan dengan syariat zakat itu sendiri jika tidak diatur dengan cara yang berbeda dan khusus.

Secara normatif pendapatan asli daerah adalah pendapatan yang diperoleh daerah berdasarkan peraturan daerah sesuai dengan peraturan perundangundangan dan hasilnya dimanfaatkan untuk penyelenggaraan tugas-tugas pemerintah dan kegiatan pembangunan dalam rangka mengisi kemandirian otonomi daerah. Oleh karena itu, jika zakat adalah PAD murni maka zakat seharusnya dapat dimanfaatkan untuk membiayai tugas- tugas pemerintah dan pembangunan tidak hanya terikat dengan 8 asnaf Mustahik zakat tersebut.

Ketentuan zakat sebagai pendapatan asli daerah sudah diatur dalam Undang undang Pemerintahan Aceh, konsekuensi logisnya adalah dana zakat ini seharusnya boleh digunakan untuk membiayai belanja daerah (sebagaimana PAD umumnya). Kondisi ini mencederai ketentuan syariah yang telah mengatur keleluasaan pengelolaan zakat yang dilakukan oleh amil (Baitul Mal) untuk para mustahik yang telah ditentukan dalam masing-masing asnaf. Kenyataan inilah yang sedang terjadi di Aceh, baik yang dihadapi oleh Baitul Mal Provinsi maupun Kabupaten/Kota yang sampai saat ini belum ada penyelesaiannya secara konkrit dan komprehensif. Permasalahan utamanya adalah belum adanya pengaturan

${ }^{20}$ Hayatullah., Op.Cit., 18. 
khusus ketika zakat menjadi penerimaan PAD (baik sebagai PAD Aceh maupun PAD Kabupaten/Kota).

Zakat sebagai pendapatan asli daerah murni tidak dapat disalurkan karena harus menunggu pengesahan APBA walaupun zakat sudah terkumpul. Hal ini disebabkan karena zakat dimasukkan dalam pendapatan asli daerah yaitu harus mengikuti segala hal yang telah ditetapkan dalam APBA sehingga jumlah yang disalurkan harus terikat dengan jumlah yang telah ditetapkan oleh APBA, artinya jumlah yang disalurkan harus sama dengan jumlah yang diterima, jika realisasi penerimaan zakat melebihi dari yang telah ditetapkan di APBA maka telah sesuai dengan peraturan keuangan daerah yang ada kelebihan itu tidak dapat dicairkan tetapi akan menjadi SILPA untuk tahun anggaran yang akan datang.

Ketentuan zakat sebagai pendapatan asli daerah ini tidak bertentangan dengan undang-undang yang ada . Apabila zakat masih ingin dikelola oleh pemerintah akan lebih baik jika penyebutan zakat dalam undang-undang Pemerintahan Aceh ini bukan hanya pendapatan asli daerah saja melainkan menjadi pendapatan asli daerah khusus (PAD khusus). Mengatur zakat sebagai pendapatan asli daerah khusus tidak bertentangan dengan peraturan perundang undangan manapun akan tetapi istilah pendapatan asli daerah khusus ini belum pernah diatur dalam peraturan perundang undangan yang ada di Indonesia, sehingga pengelolaan zakat di Aceh ini dapat diatur secara khusus dan memiliki regulasi tersendiri yang mengakibatkan zakat ini dapat disalurkan sebelum adanya pengesahan APBA dan para pejabat yang mengurusi hal ini pun lebih berani dalam bertindak untuk segera menyalurkan zakat ini sebelum APBA disahkan.

Masalah dalam pengelolaan zakat di Aceh ini salah satunya adalah zakat tidak dapat disalurkan sebelum APBA disahkan, apabila ada regulasi atau peraturan perundang undangan yang baru mengenai zakat atau dengan mengamandemen Undang-Undang Nomor 11 Tahun 2006 tentang Pemerintahan Aceh dengan menjadikan zakat sebagai pendapatan asli daerah khusus, sehingga dapat dikelola terpisah dan tidak harus menunggu APBA disahkan, setelah itu zakat yang tidak habis disalurkan dalam tahun berjalan tidak perlu disetor kembali ke kas daerah dan menjadi SILPA. 
Solusi terhadap kesemrautan zakat sebagai pendapatan asli daerah, maka Pergub Nomor 55 tahun 2010 tentang Tata Cara Penyotoran dan Pencairan Zakat pada Bendahara Umum Daerah, telah memberikan beberapa perlakukan khusus, misalnya, zakat dapat dicairkan sebelum APBA disahkan, zakat yang melebihi target pendapatan dapat ditarik seluruhnya, penarikan zakat mengacu kepada datadata terakhir yang disahkan Dewan Pertimbangan Syariah, sisa zakat tahun lalu dapat ditarik pada tahun berikutnya, pertanggungjawaban zakat tak mengacu pada tahun anggaran, zakat dikelola oleh Badan Pelaksana Baitul Mal Aceh, walaupun telah dibentuk Sekretariat sebagai Satuan Kerja Perangkat Daerah (SKPD) dan, beberapa pengucualian lainnya dari aturan keuangan yang berlaku secara nasional. Oleh karena itu, maka zakat sebagai pendapatan daerah harus diatur khusus dan harus diatur regulasi yang khusus mengenai zakat sebagai pendapatan asli daerah yang lebih rinci dan jelas mengenai proses penghimpunannya sampai dengan proses penyaluran.

Zakat sebagai pendapatan asli daerah ini masih harus dikecualikan dari ketentuan keuangan yang ada. Pada satu sisi pengelolaan zakat sebagai syariat Islam harus tetap independen dan mematuhi ketentuan syariat, zakat harus disalurkan kepada delapan asnaf. Pada sisi lain, harus pula memperhatikan ketentuan keuangan pendapatan asli daerah, mematuhi regulasi dan prosedur keuangan daerah.

Zakat yang ditarik dari bendahara umum daerah biasanya bukan dari sumber zakat, tapi sumber lainnya. Penarikan zakat mesti menunggu pengesahan APBA yang seringkali terlambat., sehingga muncul pertanyaan dari kalangan ulama, mengapa zakat harus dicatat dan dimasukkan dulu sebagai pendapatan asli daerah. Apakah dengan begitu, zakat yang suci ini tidak akan bercampur dengan sumber pendapatan asli daerah lainnya yang kadang masih diragukan atau samar samar kehalalan atau keharamannya. Bagaimana pula Baitul Mal Aceh dan Baitul Mal Kota dapat mengatur likuiditas zakat, sebab mekanisme pencairan dana zakat yang sangat birokratik.

Suatu kekhususan di Aceh ialah memberlakukan zakat sebagai salah satu sumber Pendapatan Asli Daerah (PAD) yang bersifat khusus, tetapi walaupun 
sebagai Pendapatan asli daerah, zakat tidak dapat digunakan untuk membiayai pengeluaran yang sudah dianggarkan dalam APBA, kecuali untuk penyaluran zakat yang sesuai dengan syariat Islam, dengan begitu zakat sebagai pendapatan asli daerah ini dapat dikatakan hanya menumpang didalam APBA dan dapat mencederai arti dari pendapatan asli daerah itu sendiri karena pada dasarnya sumber pendapatan asli daerah itu dapat digunakan untuk menyelenggarakan fungsi - fungsi daerah, sedangkan zakat dimasukkan dalam salah satu sumber pendapatan asli daerah tetapi tidak dapat digunakan untuk menyelenggarakan fungsi-fungsi daerah itu sendiri.

Apabila dalam hal ini pemerintah ingin mengintervensi pengelolaan zakat agar lebih terintegrasi, maka bisa menggunakan cara lainnya tidak perlu dengan memasukkan zakat sebagai pendapatan asli daerah yang penyalurannya baru dapat dilakukan setelah APBA disahkan yang dapat menghambat proses penyaluran zakat itu sendiri dan dana zakat itu kemudian ketika akan dicairkan harus mengikuti segala proses birokrasi dari tata cara pencairan dana pada APBA.

Salah satu cara lainnya selain memasukkan zakat sebagai pendapatan daerah khusus bukan lagi sebagai pendapatan asli daerah murni, yaitu dengan tidak memasukkan dana zakat sebagai PAD namun pengelolaan zakat dapat diintervensi dan diawasi langsung oleh pemerintah, sehingga jika zakat tidak dimasukkan dalam PAD maka zakat dapat disalurkan kapanpun tanpa harus menunggu APBA disahkan.

Pemerintah dan legislatif di Aceh, oleh karena itu dapat membuat suatu regulasi tersendiri dimana zakat dapat diatur khusus ataupun diatur terpisah atau bukan merupakan pendapatan asli daerah tetapi pemerintah tetap dapat mengintervensi dan tetap dapat mengawasi agar dana zakat itu tetap terintegrasi dengan baik sesuai dengan tujuan awal pemerintah memasukkan zakat itu sebagai pendapatan asli daerah, Sehingga zakat tetap bisa disalurkan sesuai dengan syariat Islam begitu juga zakat tidak akan mencederai pengertian dari pendapatan asli daerah itu sendiri ketika zakat itu dimasukan sebagai pendapatan asli daerah, namun tidak dapat digunakan oleh pemerintah untuk menyelenggarakan fungsi fungsi serta tugas - tugas dari Pemerintahan Aceh itu sendiri. 


\section{Penutup}

\section{A. Kesimpulan}

Berdasarkan analisis diatas, penulis dapat menyimpulkan sebagai berikut :

1. Dalam hal pengelolaan zakat, Baitul Mal Aceh mengalami kesulitan dalam proses pengelolaan, pengeluaran dan penyaluran zakat karena dana zakat baru dapat disalurkan setelah APBA disahkan oleh Dewan Perwakilan Rakyat Aceh bersama - sama dengan Gubernur, sehingga dana zakat harus mengikuti mekanisme APBA dimana jumlah penerimaan dan pengeluaran anggaran diatur relatif ketat, jadi pengesahan APBA menjadi sebuah pegangan dan tidak dapat dirubah kecuali melalui revisi anggaran, oleh karena itu ini menyebabkan apabila dana zakat yang diperoleh lebih besar daripada dana zakat yang direncanakan maka dana zakat tidak dapat disalurkan dan akan menjadi SILPA pada tahun anggaran selanjutnya.

2. Pengaturan ideal terhadap zakat ini adalah dana zakat diatur sebagai pendapatan daerah khusus atau dengan tidak memasukkan zakat sebagai pendapatan asli daerah tetapi membentuk suatu peraturan lain sehingga walaupun zakat tidak masuk dalam pendapatan asli daerah tetapi zakat tetap dapat diintervensi dan diawasi langsung oleh pemerintah.

\section{B. Saran}

Berdasarkan kesimpulan diatas maka saran yang dapat diberikan adalah sebagai berikut :

1. Sebaiknya pemerintah mengatur zakat sebagai pendapatan asli daerah khusus sehingga pengelolaan zakat tidakperlu menunggu pengesahan APBA dan apabila penerimaan dana zakat berlebih dari perencanaan maka ddana zakat tidak perlu dijadikan SILPA pada tahun anggaran berikutnya tetapi tetap dapat disalurkan hingga habis kepara para asnaf.

2. Sebaiknya pemerintah tidak memasukkan dana zakat sebagai pendapatan asli daerah tetapi membuat suatu regulasi khusus yang 
mengatur zakat secara rinci dari proses penghimpunan sampai penyaluran dan pengawasannya dengan pemerintah tetap dapat mengintervensi dan mengawasi proses pengelolaan zakat sehingga tetap sesuai dengan tujuan pemerintah memasukkan zakat sebagai pendapatan asli daerah.

\section{IV.Daftar Pustaka}

\section{A. Buku}

Al- Hamid, Abdul. Ekonomi Zakat: Sebuah kajian moneter dan keuangan syariah. Jakarta : PT raja Grafindo Persada, 2006.

Bendadeh, Shafwan. et al, Laporan Tahunan Annual Report 2014. Banda Aceh: Baitul Mal Aceh, 2014.

Bendadeh ,Shafwan. et al, Laporan Tahunan Annual Report 2015. Banda Aceh: Baitul Mal Aceh, 2015.

Hayatullah Zuboidi et al, Laporan Tahunan Annual Report 2017. Banda Aceh: Baitul Mal Aceh, 2017.

Indonesia Zakat Development Report, Menggagas arsitektur Zakat di Indones. Ciputat : Indonesia Magnificence of Zakat (IMZ), 2010 .

Qaddim Zallum., Abdul, Sistem Keuangan Negara Khalifah. Jakarta selatan: HTI Press,2009.

Qardawi, M. Yusuf. Hukum zakat, Studi Komparatif mengenai status dan filsafat zakat berdasarkan Qur'an dan Hadits. Diterjemahkan oleh Salman Harun, et.al, Jakarta : Litera antarNusa, 1987.

\section{B. Peraturan Perundang-undangan}

Indonesia, Undang-Undang Nomor 3 Tahun 1999 tentang Pengelolaan Zakat. , Undang-undang Nomorll Tahun 2006 tentang Pemerintahan Aceh . 
, Naskah Akademik Rancangan Undang-Undang Nomor

11 Tahun 2006 Tentang Pemerintahan Aceh.

__, Qanun Aceh Nomor10 tahun 2007 tentang Baitul Mal. , Peraturan Gubernur Nomor 6 tahun 2015 tentang Tata

Cara Penerimaan dan Pencairan Dana Zakat pada Kas Umum Aceh.

C. Website

Anonim, "Sejarah Baitul Mal Aceh", http://baitulmal.acehprov.go.id, 5 Mei 2018

Anonim, Pengertian Pendapatan Asli Daerah dan Definisi Klasifikasinya, www.landasanteori.com,2015 